\title{
ANALISIS KORELASI KINERJA KEUANGAN PERUSAHAAN DENGAN HARGA SAHAM ( STUDI KASUS BANK MANDIRI Tbk )
}

\author{
Meiffa Herfianti \\ Program Studi Manajemen, Fakultas Ekonomi, Universitas Dehasen, Bengkulu
}

\begin{abstract}
The purpose of this research is to determine the correlation between the internal performance with the stock prices of Bank Mandiri Tbk. During the period of the year 1999 up to the year of 2008. Those internal performance are Net Income, Return On Assets, Return On Equity, Net Profit Margin, and Total Assets. The stock prices of Bank Mandiri Tbk. is the closing prices each the end of year1999 up to year of 2008. The data of this research are selected from the Jakarta Stock Exchange Wacth wich is published in the year of 2008/2009. The analysis was based on the bi- variate correlation analysis of SPSS. The result shows only the performance of Return On Assets (ROA) and Net Income (NI) that having strong positive correlation with the stock prices of Bank Mandiri Tbk. The performance indicators such as Return On Equity (ROE), NetProfit Margin (NPM), and Total Assets (TA) in case of Bank Mandiri Tbk. is not relevance with the stock prices movement.
\end{abstract}

Key Words: Performance, internal, indicators, bi-variate, Net Income, Return On Assets, Return On Equity, Net Profit Margin, TotalAssets, and ClosingPrices.

\section{PENDAHULUAN}

\section{Latar Belakang}

Industri perbankan nasional telah berkembang sedemikian rupa, sehingga menjadi sangat vital peranannya bagi suatu negara. Perkembangan industri perbankan di Indonesia telah mengalami pasang surut, pernah mencapai 200 bank pada masa sebelum terjadinya krisis moneter pada tahun 1988; kemudian menyusut hanya tersisa menjadi 28 bank sampai akhir tahun 2008.

Bank Mandiri Tbk (BMRI merupakan hasil merger empat bank milik negara, dimana eks Bank Impor-Ekspor (Bank Exim) ditunjuk sebagai bank anchor (bank induk untuk merger). Sebelum dilebur menajadi Bank Mandiri Tbk (BMRI), Bank Exim adalah bank devisa yang melayani kegiatan impor-ekspor, sehingga pada waktu itu merupakan lembaga keuangan perbankan yang menjadi andalan eksportir nasional. Tetapi dalam perjalanannya, Bank Exim dengan berbagai sebab mengalami kesulitan likuiditas dan terpaksa dimerger (digabung) dengan empat bank milik negara yang juga pada waktu yang sama sedang mengalami masalah likuiditas, yaitu: Bank Bumi Daya (BBD), Bank Dagang Negara(BDN), dan Bank Pembangunan Indonesia (Bapindo). 
Setelah dilebur menjadi Bank Mandiri Tbk., maka bank tersebut berubah menjadi bank komersial dengan kepemilikan saham mayoritas tetap dipegang oleh pemerintah Republik Indonesia (67.47\% saham). Bank Mandiri Tbk menduduki ranking nomor satu dalam industri perbankan nasional dalam hal aset totalnya. Bank Mandiri Tbk. merupakan bank terbesar di Indonesia dalam hal aset, kredit, maupun deposit (dana titipan masyarakat).

Pada tahun 2007 harga saham Bank Mandiri (BMRI) pernah mencapai Rp.4000 perlembar, tetapi masih jauh dibawah harga saham Bank Rakyat Indonesia yang mencapai Rp.8300 perlembar pada tahun yang sama. Pada akhir tahun 2008 harga saham Bank Mandiri Tbk (BMRI) terpuruk menjadi Rp.1820 per lembar dibandingkan dengan harga saham Bank Rakyat Indonesia (BBRI) yang juga jatuh menjadi Rp 4550 per lembar. Jika dibandingkan dengan harga saham Bank Central Asia (BBCA), harga saham Bank Mandiri Tbk. Juga masih berada jauh di bawahnya. Harga saham Bank Central Asia (BBCA) pada tahun 2008 meskipun jatuh, tidak sampai menyentuh level Rp 2500 per lembar. Data perkembangan sepuluh tahun terakhir tentang indikator-indikator kinerja internal dan harga saham Bank Mandiri Tbk dari tahun 1999 s/d 2008 disajikan pada Tabel 1.

Tabel 1.1 NI, ROA, ROE, NPM, TA Bank Mandiri Tbk.

\begin{tabular}{|c|c|c|c|c|c|c|}
\hline \multirow{2}{*}{ Tahun } & \multicolumn{5}{|c|}{ Indikator Kinerja Internal } & Harga Saham \\
& NI & ROA & ROE & NPM & TA & (BBRI) \\
\hline 1999 & $\begin{array}{c}1.000 \\
\text { (milyar) }\end{array}$ & 0.75 & 12.15 & 3.80 & $\begin{array}{c}250.000 \\
\text { (milyar) }\end{array}$ & $\mathbf{6 5 0}$ \\
\hline 2000 & $\begin{array}{c}1.181 \\
\text { (Milyar) }\end{array}$ & 0.80 & 14.19 & $4.39 \%$ & $\begin{array}{c}253.355 \\
\text { (Milyar) }\end{array}$ & $\mathbf{8 0 0}$ \\
\hline 2001 & $\begin{array}{c}2.746 \\
\text { (Milyar) }\end{array}$ & 1.47 & 35.73 & $8.72 \%$ & $\begin{array}{c}262.291 \\
\text { (Milyar) }\end{array}$ & $\begin{array}{c}\mathbf{1 . 4 5} \\
\mathbf{0}\end{array}$ \\
\hline 2002 & $\begin{array}{c}3.585 \\
\text { (Milyar) }\end{array}$ & 2.32 & 40.25 & $11.25 \%$ & $\begin{array}{c}250.395 \\
\text { (Milyar) }\end{array}$ & $\begin{array}{c}\mathbf{1 . 7 5} \\
\mathbf{0}\end{array}$ \\
\hline 2003 & $\begin{array}{c}3.228 \\
\text { (Milyar) }\end{array}$ & 2.06 & 25.18 & $20.13 \%$ & $\begin{array}{c}249.435 \\
\text { (Milyar) }\end{array}$ & $\begin{array}{c}\mathbf{1 . 5 0} \\
\mathbf{0}\end{array}$ \\
\hline 2004 & $\begin{array}{c}5.256 \\
\text { (Milyar) }\end{array}$ & 3.03 & 30.18 & $27.45 \%$ & $\begin{array}{c}248.156 \\
\text { (Milyar) }\end{array}$ & $\begin{array}{c}\mathbf{3 . 8 5} \\
\mathbf{0}\end{array}$ \\
\hline 2005 & $\begin{array}{c}6.616 \\
\text { (Milyar) }\end{array}$ & 3.38 & 28.24 & $26.51 \%$ & $\begin{array}{c}256.784 \\
\text { (Milyar) }\end{array}$ & $\begin{array}{c}\mathbf{3 . 9 5} \\
\mathbf{0}\end{array}$ \\
\hline 2006 & $\begin{array}{c}1.187 \\
\text { (Milyar) }\end{array}$ & 2.00 & 6.00 & $7.00 \%$ & $\begin{array}{c}253.713 \\
\text { (Milyar) }\end{array}$ & $\begin{array}{c}\mathbf{2 . 7 7} \\
\mathbf{5}\end{array}$ \\
\hline 2007 & $\begin{array}{c}4.347 \\
\text { (Milyar) }\end{array}$ & 3.40 & 19.07 & $5.20 \%$ & $\begin{array}{c}319.086 \\
\text { (Milyar) }\end{array}$ & $\begin{array}{c}\mathbf{3 . 7 7} \\
\mathbf{5}\end{array}$ \\
\hline 2008 & $\begin{array}{c}3.953 \\
\text { (Milyar) }\end{array}$ & 1.70 & 18.10 & $23.80 \%$ & $\begin{array}{c}318.671 \\
\text { (Milyar) }\end{array}$ & $\mathbf{1 . 8 2}$ \\
\hline
\end{tabular}

Sumber: JSX Monthly Statistics 2006/2009.

Informasi yang tertera pada tabel 1 di atas seolah-olah memperlihatkan adanya hubungan searah antara beberapa indikator kinerja internal dan harga saham Bank 
Mandiri Tbk. Oleh sebab itu perlu dilakukan penelitian tentang kemungkinan adanya pengaruh indikator-indikator kinerja internal terhadap harga saham Bank Mandiri Tbk. selama periode waktu dari tahun 1999 s/d 2008. Indikator-indikator kinerja internal yang terdiri dari Net Income (NI), Return On Assets (ROA), Return On Equity (ROE), Net Profit Margin (NPM), dan Total Assets (TA) secara normatif dianggap sebagai proksi (keterwakili) kinerja internal Bank Mandiri Tbk. Artinya kinerja tersebut merupakan prestasi manajemen Bank Mandiri Tbk. Sedangkan harga saham Bank Mandiri Tbk. Adalah kinerja eksternal, di luar kendali manajemen bank karena ditentukan oleh kekuatan permintaan dan penawaran saham di pasar modal.

Tujuan umum yang hendak dicapai oleh manajemen Bank Mandiri Tbk. adalah memaksimalkan nilai kekayaan pemegang saham yang salah satu indikatornya adalah harga penutupan akhir tahun saham bank yang bersangkutan. Untuk mencapai tujuan tersebut manajemen Bank Mandiri Tbk. berupaya meningkatkan margin keuntungan yang disebut Net Profit Margin (NPM). Margin keuntungan adalah selisih antara pendapatan dan biaya-biaya yang dikeluarkan, sehingga merupakan tingkat pencapaian efisiensi dalam pengelolaan keuangan perbankan. Adanya kenyataan bahwa di satu sisi Bank Mandiri Tbk. telah berhasil meraih sejumlah predikat yang menunjukkan peringkat keunggulan dalam industri perbankan nasional, tetapi disisi lain harga saham bank yang bersangkutan masih jauh dibawah harga saham Bank Rakyat Indonesia (BBRI) merupakan fenomena yang tidak logis. Terutama dalam kasus ini, seolah-olah tidak ada keterkaitan antara indikator Total Assets (TA) dengan harga saham akhir tahun yang merupakan cerminan kepercayaan pasar kepada kemampuan manajemen Bank MandiriTbk.

\section{TINJAUAN PUSTAKA}

\section{IndikatorKinerjaBank}

Indikator kinerja bank sangat banyak, baik yang termasuk kategori internal (kinerja manajemen bank) maupun dari eksternal (keseimbangan pasar). Secara umum, pengertian kinerja atau performance adalah perkembangan total yang menunjukkan hasil dari kegiatan yang telah dilaksanakan perusahaan selama periode waktu tertentu. Oleh sebab itu kinerja perbankan, sesuai dengan pengertian Malayu (2008), adalah penilaian hasil-hasil kerja manajemen bank untuk mencapai posisi yang diinginkan dalam industri perbankan.

Pengertian tentang kinerja menurut Kasmir (2008) tersebut masih terbatas pada sumber daya manusia, belum menjelaskan tentang kinerja sumber daya keuangan perusahaan. Berdasarkan pengertian kinerja tersebut, maka kinerja dapat dibedakan menjadi kinerja keuangan (financial performance) dan kinerja nonkeuangan (nonfinancial performance). Kinerja keuangan perusahaan merupakan rasio-rasio keuangan yang dibentuk dari laporan keuangan perusahaan selama jangka waktu tertentu, biasanya setiap akhir tahun. 
Menurut Djoko (2008) kinerja keuangan perbankan dapat diukur dari beberapa indikator, antara lain keuntungan bersih (Net Income: NI), tingkat pengembalian terhadap aset atau disebut Return On Assets (ROA), tingkat pengembalian terhadap modal sendiri atau disebut Return On Equity (ROE), marjin keuntungan bersih atau disebutNet ProfitMargin(NPM),dansebagainya.Kinerja keuangan juga bisa diukur dari kepercayaan pasar, misalnya indikator harga saham, indikator frekuensi perdagangan saham, dan volume perdagangan saham di bursa efek.

Mudrajad \& Suhardjono (2002: 559) membagi kinerja keuangan perbankan dari tiga sudut pandang (kepentingan), yaitu: sudut pandang pemilik (pemegang saham), sudut pandang penitip dana (kreditor), dan sudut pandang manajemen (internal) bank itu sendiri. Dari sudut pandang pemilik, maka kinerja perbankan diukur dari: 1) tingkat pengembalian terhadap modal saham (ekuitas) atau disebut Return On equity (ROE); 2) laba bersih per lembar saham atau disebut Earning Per Share (EPS), 3) pembagian dividen per lembar saham atau disebut Dividend Per Share (DPS); dan 4) rasio antara harga per lembar saham terhadap laba bersih yang dihasilkan atau disebut Price Earning Ratio (PER). Indikator-indikator kinerja menurut pengertian tersebut mewakili kepentingan pemegang saham bank, sehingga semakin baik kinerja bank yang diukur dari indikator-indikato tersebut, semakin terpenuhi kepentingan pemegang saham. Salah satu tujuan perusahaan, termasuk perbankan adalah untuk memaksimalkan kekayaan pemegang saham. Tujuan tersebut dapat dicapai melalui tingginya harga saham perbankan di bursa efek (Brigham \& Houston, 2004).

Selanjutnya dari sudut pandang nasabah (masyarakat penitip dana), maka kinerja bank diukur dari: 1)rasio lancar atau disebut Current Ratio (CR), 2)rasio cepat atau disebut Quick Ratio, dan 3) pola aliran kas atau disebut Cash Flow Pattern (CFP), 4) rasio antara hutang dan modal saham atau disebut Debt to Equity Ratio (DER), dan rasio antara hutang terhadap aset keseluruhan atau disebut Debt to Assets Ratio (DAR). Pada dasarnya penitip dana (nasabah) berkepentingan terhadap likuiditas dan rentabilitas bank, yaitu dalam artian bahwa bank tidak pernah kekurangan dana lancar dan mampu melunasi segala hutang- hutangnya tepat pada waktunya. Semakin besar rasio antara aset dan hutang bank, maka semakin terjamin kepentingan penitip dana.

\section{Kinerja Internal dan Eksternal Bank}

Berbagai jenis kinerja bank yang dibuat sesuai dengan keperluan, tetapi yang dipublikasikan oleh Bursa Efek Indonesia adalah:

1)Aset keseluruhan milik bank atau disebut Total Assets (TA), yang terdiri dari kredit, surat-surat berharga yang diperdagangkan, kas dan simpanan pada bank lain, dan aset lain-lain yang tidak termasuk dalam salah satu kategori ketiga jenis aset tersebut.

2) Penerimaaan atau disebut Revenue(Rev), baik yang berasal dari pendapatan bunga maupun dari pendapatan bukan-bunga;

3) Pendapatan bersih atau disebut Net Income (NI), yaitu selisih antara pendapatan (Revenue) dan biaya-biaya (Expenses);

4) Kapitalisasi pasar atau disebut Market Capitalization (MCap); 
5) Rasio kecukupan modal atau disebut Capital Adequacy Ratio (CAR), dan

6) Dana titipan pihak ke tiga atau disebut Third Party Funds (TPF).

Keenam jenis kinerja keuangan perbankan tersebut dikategorikan sebagai kinerja fundamental bisnis perbankan. Pendapatan Bersih atau disebut Net Income (NI) bagi bank adalah selisih antara seluruh penerimaan (baik dari bunga maupun dari fee atas jasa-jasa bank) dan semua biaya-biaya (baik biaya bunga yang diberikan kepada penitip dana maupun biaya-biaya operasional lainnya). Brigham dan Weston (2004) menjelaskan bahwa laba bersih merupakan arus kas yang tersisa untuk dibagikan kepada pemegang saham. Besar-kecilnya laba bersih menentukan jumlah pembagian (dividen) yang akan diterima oleh pemegang saham.

Disamping indikator-indikator kinerja yang telah dijelaskan di atas, maka seringkali juga disebutkan dalam laporan tahunan perbankan tentang beberapa indikator kinerja selain yang dipublikasikan oleh Bursa Efek Indonesia tersebut di atas. Beberapa indikator kinerja yang juga dilaporkan adalah:

1) Kredit macet atau disebut Non Performed Loan (NPL);

2) Dana Pihak Ke tiga (DPK); dan

3) Penyaluran kredit kepada masyarakat, terutama dalam membantu investasi sektor riil. Ketiga indikator kinerja tersebut dianggap penting dalam menilai fungsi bank sebagai lembaga intermediary (perantara) antara masyarakat penitip dana dan masyarakat yang memerlukan dana, terutama pengusaha yang tergolong dalam Usaha Mikro Kecil dan Menengah (UMKM). Indikator-indikator kinerja tersebut juga dapat dijadikan petunjuk terhadap keberhasilan Bank Sentral dalam melaksanakan fungsinya sebagai bank pengawas terhadap bank umum komersial (Martono,2008).

\section{Hubungan Kinerja Internal dan Eksternal}

Kinerja internal adalah prestasi keuangan yang diciptakan oleh manajemen perbankan, sedangkan kinerja eksternal tercipta dari luar manajemen. Kinerja eksternal terjadi karena penghargaan investor yang diujudkan dalam perilaku investasi di pasar modal. Perbedaan antara kinerja internal dan kinerja eksternal terletak pada dasar pengukurannya. Kinerja internal diukur berdasarkan indikator-indikator kinerja keuangan bank yang informasinya diolah dari Neraca dan Laporan Laba-Rugi bank dalam satu semester atau satu tahun. Sedangkan kinerja eksternal diukur dari informasi pasar keuangan yang dipublikasikan oleh Bursa Efek Indonesia (Tedy,2008).

Kinerja eksternal diolah dari informasi pasar keuangan.Oleh sebab itu kinerja internal seringkali disebut kinerja fundamental yang berisi tentang hasil-hasil 
prestasi keuangan internal perusahaan selama kurun waktu tertentu. Sedangkan kinerja teknikal seringkali disebut kinerja teknikal hanya berisi informasi pasar perdagangan saham-saham di Bursa Efek Indonesia (Tedy, 2008).

Meskipun sumber-sumber informasi yang digunakan dalam pengukuran kinerja internal (fundamental) berbeda dengan kinerja eksternal (teknikal), dalam hal tujuan bank sama dengan tujuan perusahaan publik pada umumnya, yaitu untuk memaksimalkan nilai yang direfleksikan oleh harga saham di Bursa Efek Indonesia (BEI). Oleh sebab itu secara teoritis harus ada korelasi antara indikator-indikator kinerja internal seperti Net Income (NI), Net Profit Margin (NPM), Return On Assets (ROA), Return On Equity (ROE), Total Assets (TA) yang merupakan fundamental perusahaan dan kinerja eksternal seperti harga saham yang secara teknikal dibentuk oleh kekuatan penawaran dan permintaan saham di bursa efek.

Secara konsepsional dapat diduga bahwa kinerja teknikal disebabkan oleh kinerja fundamental. Artinya indikator-indikator kinerja teknikal yang diolah dari informasi pasar berhubungan dengan indikator-indikator kinerja fundamental bank. Dengan demikian dapat diduga bahwa ada korelasi antara indikator- indikator kinerja eksternal (teknikal) dan indikator-indikator kinerja internal (fundamental) bank yang dipublikasikan oleh Bursa Efek Indonesia (Mudradjat dan Kuncoro, 2002).

\section{METODE PENELITIAN}

\section{Jenis dan Sumber Data}

Jenis data dalam penelitian ini adalah data sekunder, yaitu data-data yang sudah dipublikasikan oleh berbagai sumber. Data publikasi tentang harga saham Bank Mandiri Tbk.(BMRI) sudah tersedia dan bisa diakses di situs internet (http://www.duniainvestasi.com/bei/prices/stock). Laporan tahun Bank Mandiri Tbk. bisa diambil dari the Bisnis Indonesia Intelligent Unit (BIIU) yang disusun oleh Redaksi Harian Bisnis Indonesia (JSX Watch).Data sekunder dalam penelitian ini sudah diolah sedemikian rupa, sehingga memudahkan bagi peneliti untuk memilih dan menganalisisnya sesuai dengan tujuan penelitian. 


\section{Obyek Penelitian}

Obyek penelitian adalah sejumlah indikator keberhasilan Bank Mandiri Tbk. yang telah ditetapkan dalam lingkup penelitian. Indikator-indikator tersebut adalah: aset total (Total Assets), pendapatan bersih (Net Income), rasio laba bersih terhadap aset total (Return On Assets:ROA), rasio laba bersih terhadap modal sendiri (Return On Equity: ROE), dan harga penutupan akhir tahun (Closing Prices) saham Bank Mandiri Tbk (BMRI) yang diperdagangkan di Bursa Efek Indonesia.

\section{Metode Analisis Data}

Metode analisis data dalam penelitian ini menggunakan statistik korelasi antara variabel-variabel internal keuangan Bank Mandiri Tbk. Dan variabel kinerja eksternal yang dalam hal ini adalah harga penutupan saham Bank Mandiri Tbk. Analisis dilakukan dengan cara membuat deskripsi korelasi, dan interpreasi korelasi dari data-data kinerja Bank Mandiri Tbk. dan data harga saham bank yang bersangkutan yang telah dipublikasikan oleh berbagai sumber data, terutama dari sumber JSX Watch 2007-2008 yang merupakan hasil olahan data sekunder oleh staf ahli Harian Bisnis Indonesia yang tergabung dalam the Bisnis Indonesia Intelligent Unit (BIIU).

Korelasi masing-masing kinerja fundamental dan kinerja teknikal Bank Mandiri Tbk. selanjutnya diuraikan secara deskriptif untuk menentukan mana diantara indikatorindikator internal yang mempunyai korelasi dengan harga saham Bank Mandiri Tbk. Kerangka penelitian analisis korelasi antara indikator- indikator kinerja internal keuangan dan harga saham Bank Mandiri Tbk. digambarkan dalam bentuk hubungan antar variabel sebagai berikut:

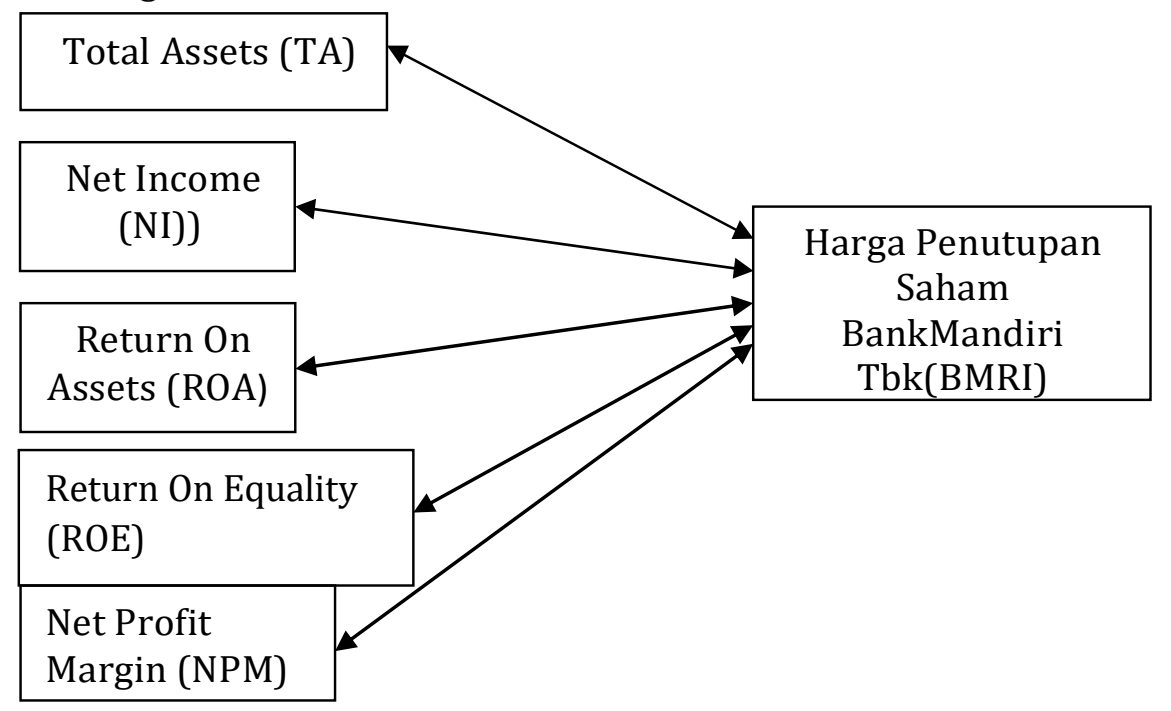




\section{HASIL PENELITIAN DAN PEMBAHASAN}

Berikutnya adalah hasil analisis terhadap korelasi bi-variat antara indikator kinerjaReturn On Equity (ROE) dan harga saham Bank Mandiri Tbk. dari tahun 1999 s/d2008. Koefisien korelasi bi-variat indikator kinerja Return On Equity (ROE) dengan harga saham Bank Mandiri Tbk.(BMRI) selama sepuluh tahun dapat dilihat pada tabel 4.4 di bawah ini.

Tabel 4.4 Korelasi bi-variat ROE dan BMRI

\begin{tabular}{|l|l|r|r|}
\hline & & ROE & BMR \\
\hline \multirow{4}{*}{ ROE } & Pearson & 1 & .135 \\
\cline { 2 - 4 } & Sig. (2-tailed) &. & .709 \\
\cline { 2 - 4 } & $\mathrm{N}$ & 10 & 10 \\
\hline \multirow{2}{*}{$\begin{array}{l}\text { BMR } \\
\text { I }\end{array}$} & Pearson & .135 & 1 \\
\cline { 2 - 4 } & Sig. (2-tailed) & .709 &. \\
\cline { 2 - 4 } & N & 10 & 10 \\
\hline \multicolumn{3}{|l}{ Sumber: Output SPSS (Lampiran 3). }
\end{tabular}

Pada tabel 4.4 di atas dapat diketahui, bahwa koefisien korelasi bi-variat antara indikator kinerja Return On Equity (ROE) dan harga saham Bank Mandiri Tbk. (BMRI) adalah sebesar 0.135, angka yang sangat kecil dan tidak signifikan pada level kesalahan 5\%. Dengan demikian ada korelasi yang signifikan antara indikator kinerja Return On Equity (ROE) dan harga saham Bank Mandiri Tbk. (BMRI) tidak dapat dibuktikan kebenarannya. Artinya pada level kesalahan 5\% tidak hubungan yang signifikan antara indikator kinerja Return On Equity(ROE) dan harga saham Bank Mandiri Tbk. Selama sepuluh tahun. dari 1999 s/d 2008. Meskipun tidak ada hubungan yang kuat antara indikator kinerja Return On Equity (ROE) dan harga saham Bank Mandiri Tbk., tetapi perlu diketahui juga perkembangan (tren) kinerja tersebut selama sepuluh tahun dari 1999 s/d 2008. Tren perkembangan kinerja Return On Equity (ROE) dari tahun 1999 s/d 2008 dapat dilihat pada Gambar 4.4. 
Gambar 4.4

Grafik Perkembangan Kinerja ROE dari tahun 1999 s/d 2008

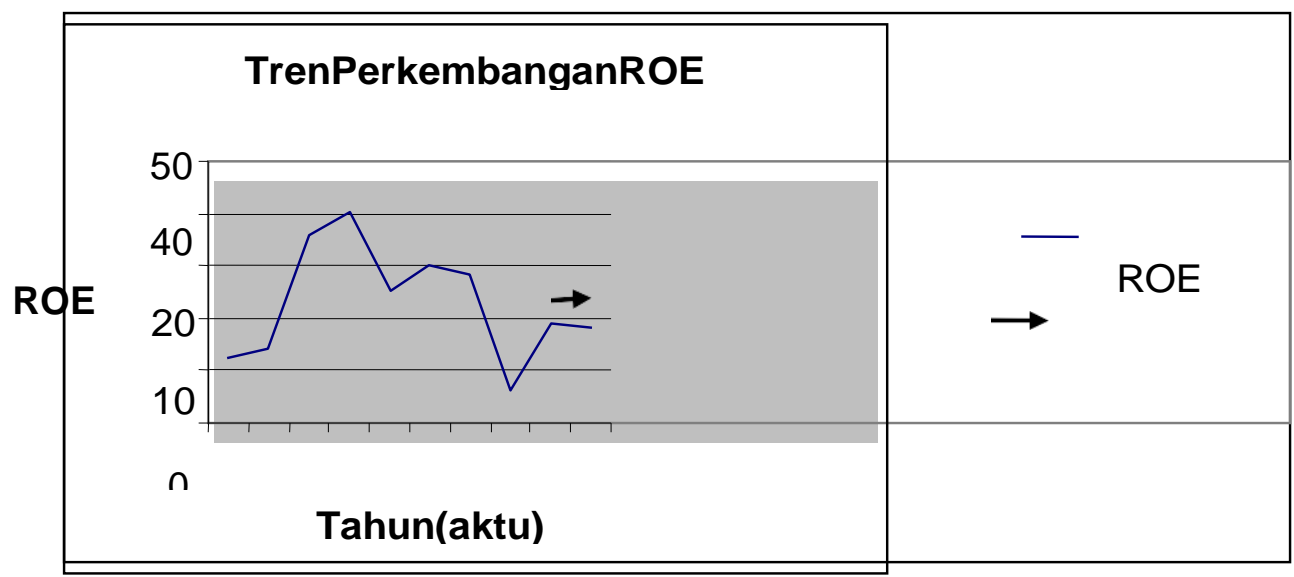

Pada gambar 4.4 grafik perkembangan kinerja Return On Equity (ROE) tersebut di atas dapat diketahui, bahwa kinerja tersebut berfluktuasi mengarah ke tren mendatar. Artinya perkembangan kinerja Return On Equity (ROE) selama sepuluh tahun dari 1999 s/d 2008 tidak mengalami kenaikan yang berarti. Hal tersebut dapat diartikan bahwa laba bersih sesudah pajak masih relative terlalu kecil dibandingkan dengan modal sendiri yang digunakan dalam kegiatan operasional Bank Mandiri Tbk dari tahun1999s/d2008.

Berikutnya adalah hasil analisis korelasi bi-variat antara indikator kinerja Net Profit Margin (NPM) dan harga saham Bank Mandiri Tbk. dari tahun 1999 s/d 2008.Koefisien korelasi yang menjelaskan kuat-lemahnya hubungan antara kedua indikator tersebut dapat dilihat pada tabel 4.5 di bawah ini.

\section{Tabel 4.5 Korelasi bi-variat NPM dan BMRI}

Correlations

\begin{tabular}{|l|l|r|r|}
\hline & & BMRI & NPM(\%) \\
\hline BMRI & Pearson Correlation & 1 & .484 \\
\cline { 2 - 4 } & Sig. (2-tailed) &. & .157 \\
\cline { 2 - 4 } & $\mathrm{N}$ & 10 & 10 \\
\hline \multirow{3}{*}{ NPM(\%) } & Pearson Correlation & .484 & 1 \\
\cline { 2 - 4 } & Sig. (2-tailed) & .157 &. \\
\cline { 2 - 4 } & $\mathrm{N}$ & 10 & 10 \\
\hline
\end{tabular}

Sumber: Output SPSS. 
Pada tabel 4.5 di atas dapat diketahui, bahwa koefisien korelasi bi-variat yang menjelaskan kuat-lemahnya hubungan antara indikator kinerja Net Profit Margin (NPM) dan harga saham Bank Mandiri Tbk. (BMRI) selama sepuluh tahun dari 1999 s/d 2008 adalah 0.484 tidak signifikan pada level kesalahan 5\%. Artinya dengan tingkat kesalahan 5\% (error 5\%) ternyata hubungan antara indiaktor kinerja Net Profit Margin (NPM) dengan harga saham Bank Mandiri Tbk. (BMRI) tidak signifikan. Angka koefisien korelasi bi-variat indicator kinerja Net Profit Margin (NPM) dengan harga saham Bank Mandiri Tbk. (BMRI) hanya 0.484 atau di bawah 0.500. Dengan demikian dapat diartikan, bahwa hubungan antara indicator kinerja Net Profit Margin (NPM) dan harga saham Bank Mandiri Tbk. (BMRI) adalah lemah, meskipun positif (searah). Selanjutnya bias ditafsirkan bahwa mesipun kinerja Net Profit Margin (NPM) mengalami kenaikan selama sepuluh tahun terakhir, hal tersebut tidak diikuti oleh kenaikan harga saham Bank Mandiri Tbk. (BMRI) secara proporsional. Dengan kata lain, jika kinerja Net Profit Margin (NPM) mengalami kenaikan, maka harga juga mengalami kenaikan tetapi dalam prosentase yang jauh lebih kecil dibandingkan dengan prosentase kenaikan kinerja Net Profit Margin (NPM).

Untuk mengetahui perkembangan indikator kinerja Net Profit Margin (NPM) dapat dilihat pada grafik tren kinerja tersebut pada gambar $4.5 \mathrm{di}$ bawah ini.

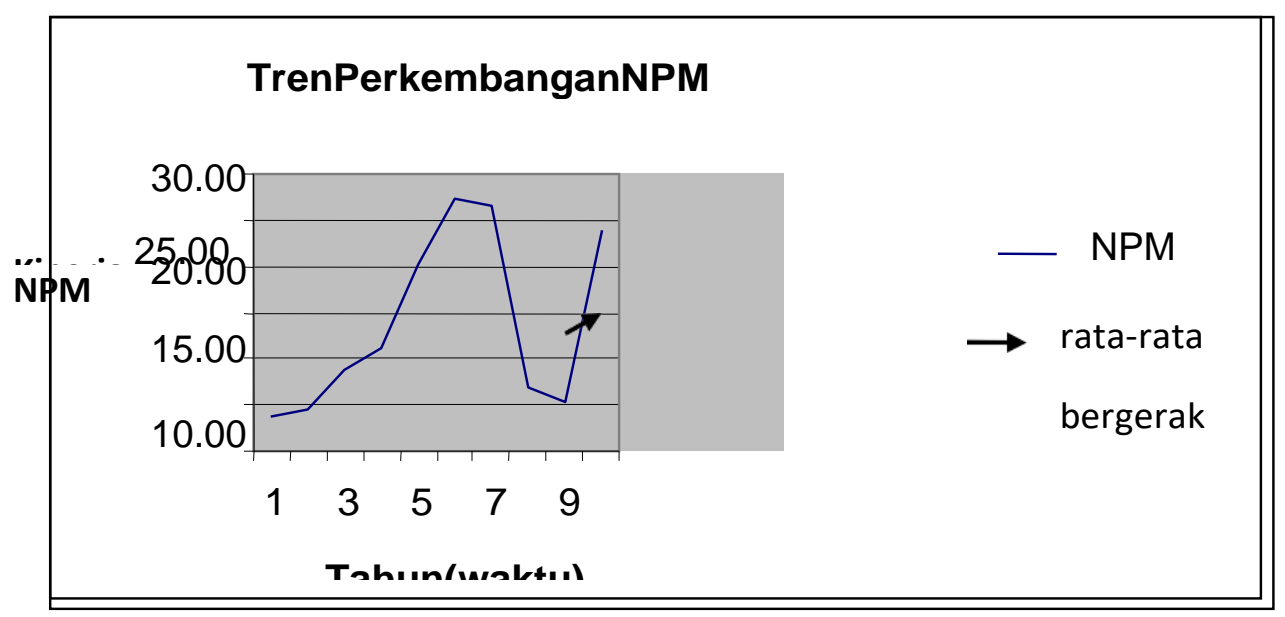

Gambar 4.5. Grafik Tren Perkembangan Kinerja NPM dari tahun 1999 s/d 2008. 
Gambar 4.5 memperlihatkan tren meningkat setelah tahun 2008 (garis panah ke atas). Garis panah mengarah ke atas dibuat dari tren rata-rata bergerak selama sepuluh tahun yang memperlihatkan arah kenaikan yang semakin tinggi. Tren tersebut bias diartikan sebagai indikasi bahwa kinerja Net Profit Margin (NPM) Bank Mandiri TBk. semakin meningkat, meskipun demikian tidak diikuti oleh peningkatan harga sahamnya (BMRI) secara proporsional.

Kinerja Net Profit Margin (NPM) merupakan salah satu ukuran keberhasilan manajemen Bank Mandiri Tbk. Dalam meningkatkan efisiensi, yaitu mengurangi biaya-biaya yang tidak relevan dengan operasional bank tanpa mengurangi kualitas layanan kepada masyarakat. Meskipun demikian terbukti bahwa peningkatan kinerja Net Profit Margin (NPM) kurang mendapatkan respon pasar, terbukti dari harga saham Bank Mandiri Tbk. (BMRI) yang tidak berkorelasi secara kuat terhadap kinerja Net Profit Margin (NPM).

Berikutnya yang terakhir adalah hasil analisis korelasi bi-variat antara indikator kinerja Total Assets (TA) dan harga saham Bank Mandiri Tbk. (BMRI) selama sepuluh tahun dari 1999 s/d 2008. Koefisien korelasi bi-variat yang menjelaskan kuat-lemahnya hubungan antara indikator kinerja Total Assets (TA) dan harga saham Bank Mandiri Tbk. dalam masa sepuluh tahun tersebut dapat dilihat pada tabel 4.6 di bawah ini.

Tabel 4.6. Korelasi bi-variat TA dan BMRI Correlations

\begin{tabular}{|l|l|r|r|}
\hline & & BMR & TA \\
\hline \multirow{3}{*}{ BMR } & Pearson & 1 & .235 \\
\cline { 2 - 4 } & Sig. (2-tailed) &. & .513 \\
\cline { 2 - 4 } & N & 10 & 10 \\
\hline \multirow{2}{*}{ TA } & Pearson & .235 & 1 \\
\cline { 2 - 4 } & Sig. (2-tailed) & .513 &. \\
\cline { 2 - 4 } & $\mathrm{N}$ & 10 & 10 \\
\hline
\end{tabular}

Sumber: Output SPSS.

Pada tabel 4.6 di atas dapat diketahui bahwa koefisien korelasi bi-variat yang menjelaskan kuat-lemahnya hubungan antara indikator kinerja Total Assets (TA) 
dan harga saham Bank Mandiri Tbk. (BMRI) selama sepuluh tahun dari $1999 \mathrm{~s} / \mathrm{d}$ 2008 adalah 0.235 tidak signifikan pada level kesalahan 5\%. Angak koefisien korelasi bi-variat yang menjelaskan kuat-lemahnya hubungan antara indikator kinerja Total Assets (TA) dan harga saham Bank Mandiri Tbk. (BMRI) sebesar 0.235 tersebut termasuk kategori hubungan yang lemah karena kurang dari 0.500. Kinerja Total Assets (TA) secara teoritis berhubungan dengan harga saham bank, tetapi dalam kasus Bank Mandiri Tbk. Ini tidak terbukkti ada korelasi yang signfikan antara indikator kinerja Total Assets (TA) dan harga saham Bank Mandiri Tbk. Penyimpangan tersebut disebabkan sebagian besar saham (67.47\%) masih dipegang oleh pemerintah Indonesia. Oleh sebab itu respon pasar terhadap perkembangan kinerja Total Assets (TA) menjadi tidak kelihatan karena pasar (investor) hanya dibolehkan memperdagangkan sebagian kecil dari saham Bank MandiriTbk.

\section{PEMBAHASAN}

Dari kelima indikator kinerja internal Bank Mandiri Tbk., yaitu: NI (Net Income), ROA (Return On Assets), ROE (Return On Equity), NPM (Net Profit Margin), dan TA (Total Assets); terbukti dari hasil analisis korelasi bi-variat bahwa hanya kinerja Net Income (NI) dan Return On Assets (ROA) yang mempunyai hubungan searah (positif) terhadap harga saham Bank Mandiri TBk. (BMRI), dimana hubungan tersebut signfikan pada level kesalahan 5\% terhadap NI (Net Income) dan 1\% terhadap ROA (Return On Assets). Indikator kinerja lainnya, yaitu: ROE (Return On Equity), NPM (Net Profit Margin), dan TA (Total Assets) tidak mempunyai hubungan yang signifikan dengan harga saham Bank Mandiri Tbk (BMRI).

Hubungan antara kinerja NI (Net Income), ROA (Return On Assets), dan harga saham Bank Mandiri Tbk. (BMRI) selanjutnya diperjelas dengan grafik perkembangan ketiga indikator kinerja, yaitu: garis merah tipis mewakili Net Income (NI), garis merah tebal mewakili Return On Assets (ROA), dan garis hitam tipis mewakili harga saham Bank Mandiri Tbk. (BMRI) dapat dilihat pada Gambar 4.6. 


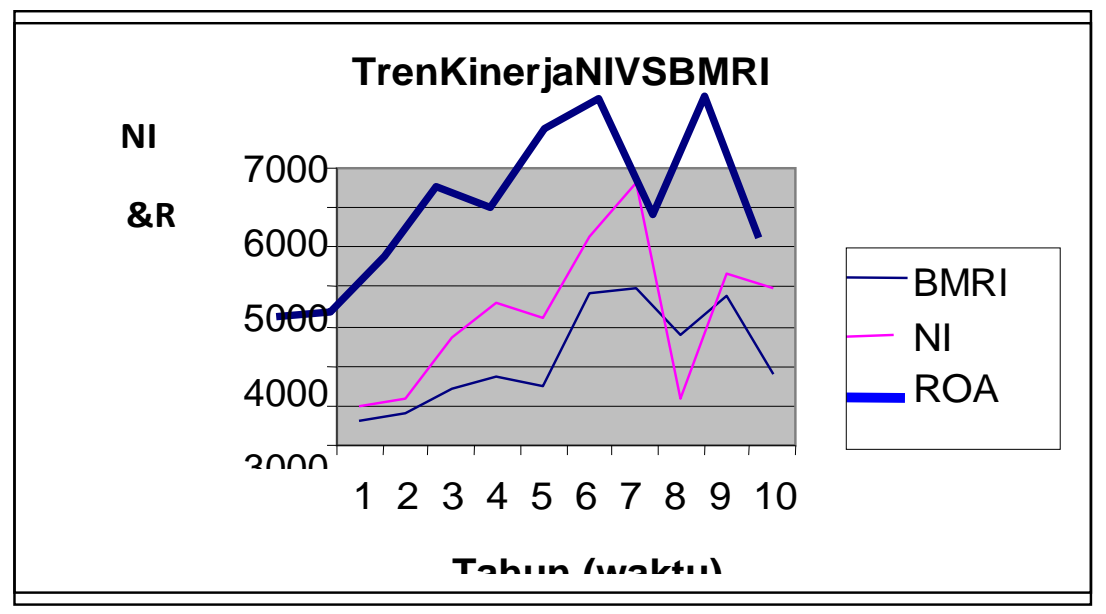

Gambar 4. 6. Grafik Tren Kinerja NI, ROA, dan BMRI.

Pada gambar 4.6 di atas dapat diketahui dengan jelas, bahwa ada keselarasan yang sangat kuat antara garis biru tebal (tren Return On Assets: ROA) dan garis hitam tipis (tren BMRI). Begitu juga ada keselarasan yang cukup kuat antara garis merah tipis (tren Net Income: NI) dan garis hitam tipis (tren BMRI). Dengan demikian disamping terbukti mempunyai koefisien korelasi bi-variat yang signifikan, hubungan tersebut bisa diketahui dari tren ketiga indikator kinerja tersebut yang mempunyai hubungan searah (positif). Disamping itu pada gambar 4.6 di atas juga dapat diketahui, bahwa harga saham Bank Mandiri Tbk (BMRI) pada tahun 2005 dan 2006 sempat mengalami penurunan karena sedikitnya saham bank tersebut yang diperdagangkan di Bursa Efek Indonesia (BEI). Pada akhir tahun 2006, pemerintah memborong pembelian tutup tahun untuk sejumlah saham perusahaan milik swasta guna mendorong kenaikan Indeks Harga Saham Gabungan (IHSG) supaya tembus ke level Rp.2000. Kebijakan tersebut justru mengurangi minat investor untuk membeli saham Bank Mandiri Tbk (BMRI) yang menyebabkan harganya terkoreksi. Pada tahun 2007 harga saham Bank Mandiri Tbk. mengalami kenaikan yang cukup drastis, tetapi pada akhir tahun 2008 harganya jatuh. Kejatuhan harga saham Bank Mandiri Tbk. pada akhir tahun 2008 dipicu oleh krisis finansial global yang melanda industry perbankan di Indonesia. 


\section{KESIMPULAN}

Setelah dilakukan analisis dan pembahasan yang telah diuraikan pada bab-bab sebelumnya serta pengujian yang telah dilakukan maka dapat diambil kesimpulan sebagai berikut :

1. Maka terbukti dari lima indikator kinerja internal yang diteliti, hanya dua yang mempunyai hubungan positif signifikan dengan harga saham Bank Mandiri Tbk (BMRI). Kedua indikator kinerja yang mempunyai hubunan positif dengan harga saham Bank Mandiri Tbk. (BMRI) tersebut adalah Return On Assets (ROA) dan Net Income (NI). Dengan demikian dapat disimpulkan bahwa harga saham Bank Mandiri Tbk (BMRI) berhubungan erat, positif, dan kuat dengan kinerja pendapatan bersih (Net Income: NI) serta rasio pendapatan bersih terhadap asset total (Total Assets: TA) bank yang tersebut.

2. Dalam kasus Bank Mandiri Tbk. terbukti bahwa respon pasar yang diperlihatkan oleh harga saham bank tersebut sangat ditentukan oleh kemampuan manajemen dalam menghasilkan laba bersih dan asset bank yang digunakan dalam operasionalnya. Prestasi manajemen Bank Mandiri Tbk dalam meningkakan laba bersih yang lebih besar bersamaan dengan aset total yang semakin meningkat merupakan pegangan bagi investor dalam menilai prospek bank yang bersangkutan.

3. Bagi investor keberhasilan meningkatkan laba bersih yang lebih tinggi dibandingkan dengan peningkatan aset bank merupakan pertanda bahwa Bank Mandiri Tbk. akan semakin kuat posisinya dalam industri perbankan. Keyakinan investor terhadap prospek Bank Mandiri Tbk. telah mendorong kenaikan harga saham bank tersebut.

\section{SARAN}

Berdasarkan hasil analisis dan kesimpulan yang telah diuraikan, maka saran yang dapat diberikan adalah sebagai berikut:

1. Bagi manajemen Bank Mandiri Tbk. disarankan untuk selalu meningkatkan pendapatan bersih yang lebih tinggi, bersamaan dengan itu juga meningkatkan asetnya. Manajemen Bank Mandiri Tbk. Harus meningkatkan rasio antara laba bersih sesudah pajak terhadap aset total yang dihimpun 
dari dana masyarakat. Rasio laba bersih sesudah pajak dengan aset total dapat ditingkatkan melalui kinerja manajer investasi supaya lebih optimal dalam alokasi penggunaan dan titipan masyarakat pada Bank Mandiri Tbk.

2. Bagi penelitian berikutnya disarankan untuk menggunakan indikator kinerja yang lebih banyak, data yang lebih banyak, dan alat analisis regresi. Dengan data yang lebih banyak, maka penggunaan alat analisis regresi akan menjadi lebih efektif. Dalam penelitian ini alat analisis regresi tidak dapat dipergunakan karena keterbatasan data, dimana jumlah data (N-data) terbatas hanya sepuluh tahun.

\section{DAFTARPUSTAKA}

Brigham, Eugene F. \& J.F. Weston, 2004. Manajemen Keuangan. Terjemahan Erlangga, Jakarta.

Djoko Retnadi, 2008. Memilih Bank Yang Sehat: Kenali Kinerja dan Pelayanannya, Jakarta Elex Media Komputindo.

JonathanSarwono,2006. Analisis Data Penelitian Menggunakan SPSS13, Yogjakarta: PenerbitAndi.

MalayuSP.Hasibuan,2008. Dasar-Dasar Perbankan. Jakarta:Intermedia. JSX

Kasmir,2008. Bank dan Lembaga Keuangan Lainnya. Jakarta:Intermedia.

Kuncoro,M.,2003. Metode Riset Untuk Bisnis dan Ekonomi: Bagaimana

Meneliti dan Menulis Tesis. Jakarta: Erlangga.

Martono, 2008. Bank dan Lembaga Keuangan Lainnya. Jakarta: Elex Media Komputindo.

Mudrajat Kuncoro \& Suhardjono, 2002. Manajemen Perbankan Teori dan Aplikasi, Edisi Pertama. Yogyakarta: BPFE UGM.

Santoso, Singgih 2007. Menguasai Statistik Era Informasi dengan SPSS 15.

Jakarta: Elex Media Komputindo.

Said Kelana Asnawi \& Chandra Wijaya, 2005. Riset Keuangan: Pengujianpengujian Empiris, Jakarta: Gramedia Pustaka Utama.

Singggih Santoso, 2005. Menguasai Statistik di Era Informasi dengan SPSS 12, Jakarta: Elx Media Komputindo.

Sutrisno \& Retno, 2001. Pengaruh Informasi Keuangan Terhadap Harga Saham Perusahaan Publik, Tesis Tidak Dipublikasikan.

Seventh Edition Watch 2007-2008, Jakarta: Aksara Grafika Pratama. Jakarta Stock Exchange, 2006. JSXLQ45, August 2006.

Tedy Fardiansyah 2008. Refleksi\& Strategi Penerapan Manajemen Resiko Perbankan Indonesia. Jakarta: Alex Computindo.

Tim Penulis Laporan Triwulan I-2003, Bank Indonesia.Jurnal Buletin Ekonomi Moneter dan Perbankan, volume 5, Nomor 4, Maret 2003. 